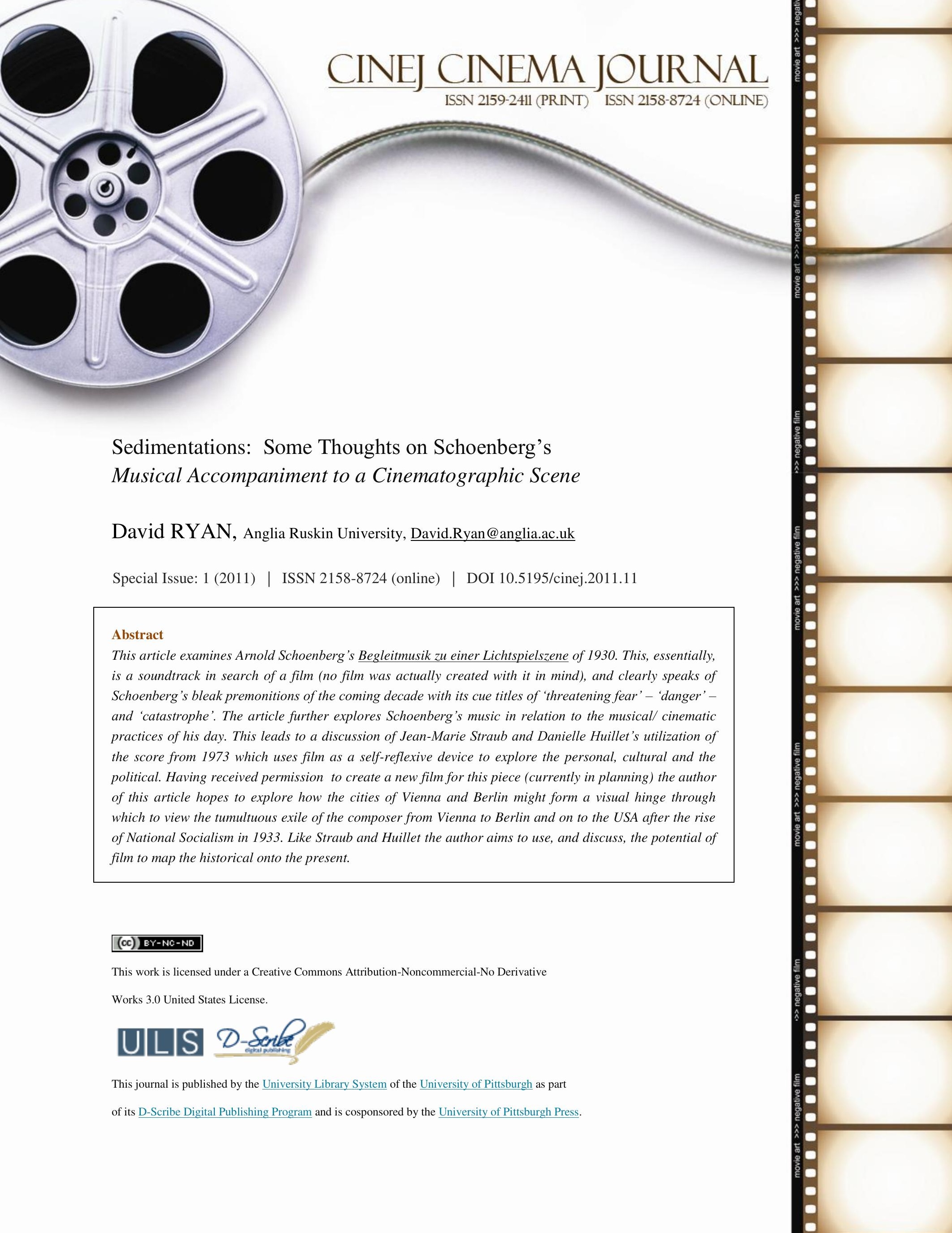




\section{Sedimentations: Some Thoughts on Schoenberg's Musical Accompaniment to a Cinematographic Scene}

\section{Prologue}

Having been intrigued by Arnold Schoenberg's Begleitmusik zu einer Lichtspielszene (1929-30), translated as 'Musical Accompaniment to a Cinematographic Scene', and receiving permission from Lawrence Schoenberg, the composer's son, to produce a video piece for this extraordinary piece of music, it seemed natural to use this as a pivot around which to address filmic cultural encounter. My initial response to this video project was to conceive filming the two great cites that formed a backdrop to Schoenberg's early life and work: Berlin and Vienna, with the music operating as a kind of hinge between the filmed cityscapes. Why this might be a first response to the music is an interesting question, but it is one has remained and still informs my approach to the possibility of realizing this project in the future. This is addressed toward the end of the essay and what precedes it is a sort of responsive cartography of obliquely related ideas and issues: firstly, Musical Accompaniment to a Cinematographic Sequence is addressed in the context of Schoenberg's music and the cinema of its day. In examining this piece it is necessary to attempt to reconstruct Schoenberg's intentions, and, indeed, ask what can be done with such music in realizing a filmic response. Secondly, and to this end, I intend to focus on the Jean-Marie Straub (1933) and Daniele Huillet (1936-2008) realization of the film (1973) because of the sheer dedication with which these author/directors have attempted to think through, with, and even against Schoenberg in their various investigations of his music. Finally, the more personal question may well be asked of why Vienna and Berlin? This is related to, albeit at the periphery, the questions around cultural encounter and the cinematic cityscape that will be touched on at the end.

\section{Schoenberg and Music for the Films}

Schoenberg's relationship with cinematic art might best be described as oblique. And yet one of the most persistent accusations of Schoenberg's music by a first-time listener is that it 'sounds like film music'. There are various reasons for this response. Firstly, the rather trivial one that movie music is the most 'known' reservoir of vaguely modern classically sounding music; secondly, the 'visionary' quality of Schoenberg's music and its seemingly heightened emotional intensity appears so vivid. Schoenberg's early music takes us from the Vienna of the 1890s in his Wagnerian songs and famously lush Romantic Verklärte Nacht (1899) to a response to symbolism, in particular Stefan George's poems, with his phase of so-called 'free' atonal composition lasting from 1907 up to the violent interruption of the First World War. Within this period Schoenberg is perhaps at his most revolutionary in demanding, literally, new sound worlds and new conceptions of both pure music and drama, particularly with the Five Orchestral Pieces (1909), Ewartung (1909) and Peirrot Lunaire (1912) amongst many other pieces. Apart form the Five Orchestral Pieces (although descriptive titles for these were added at the request of the publisher, and much to Schoenberg's chagrin) text remains a key spark during this period, bringing into being an almost hallucinogenic intensity to musical word painting. No doubt symbolist poetry of the 1890s is partially responsible for opening up this world with its over-ripe sensuality and decadent connotations of correspondences between the senses. The British composer Constant Lambert, a critic of the Schoenberg school in the 1930s, saw this whole phase of atonality as a period when composers were simply realizing the technical and emotional means to catch up with the literature of a previous generation:

CINEJ Cinema Journal: Sedimentations: Some Thoughts on Schoenberg's Musical...

Special Issue: 1 (2011) | ISSN 2158-8724 (online) | DOI 10.5195/cinej.2011.11 | http://cinej.pitt.edu 
The complete break up of the traditional Teutonic technique released a new world of sound and a new world of sensation. Like a repressed character who, having at last lost his inhibitions, flings himself into debauch with a hardiness and gusto that would astonish the accustomed pagan, so the composer, suddenly conscious of his nerves, almost lost consciousness of any other faculties and concentrated in one single generation the neurasthenia of fifty years of literature. ${ }^{1}$

This emphasis on sensation, apparent in the Five Orchestral Pieces and Ewartung in particular, had a delayed reaction in relation to film music. It was only by the late 1940s that any direct application of atonalism started to creep in.

Accompaniments to film music contemporary to Schoenberg's 1909 scores generally operated as a potpourri of quotation from standard repertoire such as Tchaikovsky or Gounod. Before the standardization of orchestras for silent film it was often a pianist, organist or an ad hoc group who accompanied screenings. William Alwyn, a distinguished British film composer of his day, would recall an early foray into the cinema pit aged eleven in 1916 articulating the provincial conditions of the silent film music of the time:

In front of me on the music stand was a thick stack of music; Poet and the Peasant and Zampa were in the better class $[\ldots]$ it was a mixed bag of sentimental favourites and an album of specially composed film music designed to meet any known situation. Also on the desk was a piece marked Theme which I was told by my mentor to keep separate from the rest and at a given signal from the leader (two raps on the desk?) to abandon whatever I was playing and dive abruptly into the theme [...] The essential link in the performance was the pianist who bound this hotch-potch of music together with his rapid modulations and improvised chords. ${ }^{2}$

This essentially improvised, or roughly hewn, tapestry of quotations of known standard or popular repertoire works served as both mnemonic and emotional ballast to the visuals. As Rick Altman has pointed out, the development of silent cinema and sound cannot be totally subsumed under the iron law of Wagnerian leitmotif (as it often is) constituting any homogenously consistent approach, though it was certainly one strong influence, from the period of 1900 through to the 1920s. It was in fact much more organic: traversing music hall styles, light music, orchestral repertoire, specific improvisations determined by cue sheets, to fully-fledged composed orchestral scores. Within these genres, though in different forms, the theme and its transformation for particular scenes remained a key issue. Recognizable songs later became an important commercial adage and prefigured their usage in sound films in the 40s, 50s and 60s, but made an early appearance accompanying film reels. Altman suggests that, within early film the use of, for example, Stephen Foster's songs worked so well,

Because they were the repositories of a cultural memory that exhibitors knew well they could bank on. In the same way, the classical pieces most often used in used by early twentieth century piano teachers were pressed into service in theaters in the early 1910s. Rubinstein's "Melody in F", Schumann's "Traumerei" and Massenet's "Elegy" were chosen not just because the musicians knew them but because they were well known to audiences, who took pleasure in discovering their favourites. ${ }^{3}$ 
In this context we can only imagine the shudder that went through the concert audience present at the first performance of Schoenberg's Five Orchestral Pieces at the Promenade concerts in London in 1912 under the baton of Henry Wood. It is said a third of the audience booed, a third nervously laughed, and the rest couldn't decide whether to laugh or boo. But that shudder, that feeling of non-recognition or incomprehension, was then translated into a sign for 'the unknown' and hence this music became the stock source for later third-rate horror movie composers. It was the only way of making sense of that strangeness of the music, to use it to illustrate such strangeness, fear or the uncanny - which the intense neurasthenia of the music, as Constant Lambert pointed out, was aptly suited.

That the raw sensations opened up by this music took decades to break into the mould of film scoring is somewhat surprising. If we look more closely at Schoenberg's activities in Vienna and Berlin we find the composer involved in the kinds of ad hoc groupings of early cinema with his involvement in a Berlin based cabaret in 1901-2 (these vaudeville contexts and popular café events were sometimes the home of early cinema projections). Schoenberg's early dramatic works are closely tied with melodrama, though far more 'fleshed out' than their early cinematic counterparts but none-the-less related. Ewartung uses a stream-of-consciousness approach not uninfluenced by his contemporary Freud, utilising an impressive athematicism, as Schoenberg's pupil Anton Webern noted, "In it, all traditional form is broken with; something new always follows according to the rapid change of expression. The same is true of the instrumentation: an uninterrupted succession of sounds never before heard. There is no bar which fails to show a completely new sound picture." 4 If we take Altman's previous comments above, such music would have frightened the life out of early cinemagoers. As has been clearly researched, the early silent cinema (when it was without music, which it rarely was) appeared to the audience as a ghostly apparition, hallucination, or something uncanny proposing a 'lack'. It was the comfort of the popular tunes and classics or the recognizable themes derived from them, the opposite of Schoenberg's music at the time that filled and domesticated this void.

But, the melodrama in Schoenberg, as a form, points to his interest in the extra-musical, in the interplay between gesture, word, and music that allows subtle shading of expression. Even in Pierrot Lunaire, the actress who commissioned the piece, Albetine Zehme, was known for her spoken melodramatic monologues with musical accompaniment, which, in its most basic terms, Pierrot is. Zehme often used traditional classical music as an accompaniment to her melodrama recitals, such as Chopin and others. Yet, on October 16 1912, however, in the Berlin Choralion-saal, dressed as Columbine, she delivered the Pierrot recitation alone on stage with Schoenberg conducting the musicians behind a screen. In another melodrama-like work, the opera Die Glucklicke Hand (190913), Schoenberg develops this interplay of gesture as spoken, sung, musical and adding here a strong visual element. In this piece Schoenberg created intricate relationship between light and colour with detailed sketches outlining shifts and co-ordinations of passages of both music and colour. Although it was completed in 1913 it had to wait until 1924 for its premiere. Four years later he delivered a lecture at Breslau on the piece detailing his concern with what might be seen as an expanded gestural approach as follows,

[...] The most decisive thing is that an emotional incident, definitely originating in the plot, is expressed not only by gestures, movement and music, but also by colours and light, and it must be evident that gestures, colours and light are treated here similarly to the way tones are usually treated that music is made with them; that figures and shapes, so to speak, are formed from individual light values and shades of colour, which resemble the forms, figures and motives of music ${ }^{5}$. 
This strong emphasis on the visual component is hardly surprising at this point in Schoenberg's career, due to his own experiments with painting (c1907-1912), which accompanied the intense atonal period, and also his friendships with painters such as Kokoschka and Kandinsky. In a fascinating missed opportunity, Schoenberg's correspondence unearths a project in 1913 to film Die Gluckliche Hand complete with his thoughts on the filmic and musical processes to be explored. This would have been the first filmed contemporary opera/experimental film, and Schoenberg expresses his wish to involve Kandinsky or Kokoschka with the hand tinting of the intense coloration of various passages. We also see that Schoenberg was abreast of early editing techniques but also demanding a new role for film beyond the burgeoning 'reality principle' being unfolded by fledgling film grammar:

My foremost wish is therefore for something the opposite of what the cinema generally aspires to. I want: The utmost unreality! The whole thing should have the effect (not of a dream) but of chords. Of music. It must never suggest symbols, or meaning, or thoughts, but simply the play of colours and forms. Just as music never drags a meaning around with it, at least not in the form which it [music] manifests itself, even though meaning is inherent in its nature, so too this should simply be like sounds for the eye, and so far I am concerned everyone is free to think or feel something similar to what he thinks or feels while hearing music. ${ }^{6}$

Here, Schoenberg predicts the origin of the completely abstract film, not realised until Hans Richter's and Walter Ruttmann's experiments in the early 1920s. While Die Gluckliche Hand was initially described by Schoenberg as 'making music with the media of the stage' the possibility of film offered a far more complete realization of this piece which was immediately grasped by the composer: "And there are a thousand things [...] that [can] be done in this medium, whereas the stage's resources are very limited." Schoenberg's vision of the musical 'accompaniment' also reflects the contemporary practices, despite his idiosyncratic and typical demands of total control and unlimited rehearsal time. Astonishingly, he even considered arranging the orchestral part for theatre organ, "Further, in large cities", he stated, "It must always be an orchestra. When and under what conditions an organ may be used cannot be said at this stage. For that, after all, depends what these organs are like. If they satisfy me I shall make no difficulties." ${ }^{7}$ Unfortunately this 1913 cinematic realization, to be completely supervised by Schoenberg came to nothing. But even from the fragmented correspondence concerning this project we can see that Schoenberg was interested in the management of the whole possibility of cinema: editing, scenography, colouration and, of course, the integration of music. That it was an atonal opera that connected with film at this point is also significant in that the evolution of sound within silent film was often seen as having its origins in popular opera with cinema itself seen as a kind of mutant operatic form. Schoenberg saw this reciprocal relation with opera necessitating a response from the then still silent cinema and vice versa: "The future of the opera depends on the future of the drama, and both have new ways forced on them by the fact of the cinema, which can offer all the theatre offers except speech." 8

It was over 15 years later that the music publishers Heinrichshofen Verlag, who specialised in music for the silent cinema, contacted Schoenberg with the possibility for writing a musical accompaniment for film. The publishers, with Schoenberg's difficult personality in mind, knew that to secure the commission they should forego 
contracting the composer to a particular film, hence the generic title, 'Musical Accompaniment to a Cinematographic Scene'. No film, therefore, was produced for Schoenberg's music, leading to the suggestion that the film in question was purely imaginary. Alban Berg, for one, was not quite satisfied by this: "I can't get over the fact that you have written a score to a film scene. Was it composed for a particular film? Or is it something for general use (in the sense, say, of a comedy overture)? [...] Of course it is a complete work of art even without film; but wouldn't it be wonderful if it could be heard synchronically (or whatever it's called!) with a film created by you.

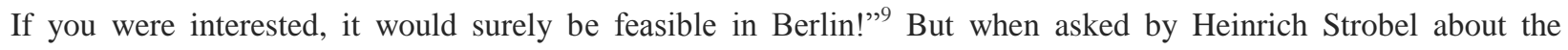
'application' of the music in 1931 in a radio broadcast which preceded a performance of the piece, Schoenberg responded tartly: "Am I to conform to a fad, like American movies, which have managed to overexploit and ruin a good thing in just two decades? [...] When I think of motion pictures, I'm thinking about those of the future, which will necessarily be more artistic. And it's those that my music will fit!" This has caused no end of problems with the piece, which has been mainly used as a concert work without film with some referring to the above as evidence of Schoenberg's intentions. Occasionally, through the decades, the score has been realized with scenes from classics of the silent cinema, usually of the horror variety. Nosferatu or The Cabinet of Dr. Caligari being obvious choices to reflect the three sections or 'cues' of Schoenberg's music: 'threatening danger', 'fear', 'catastrophe'. Needless to say, this does not do justice to the piece, and with such film choices these cues become mere illustration, but also rather than mobilizing a cinema of 'the future' it forces this music into an anachronistic position. It also reduces it to a one-dimensional cliché, echoing that of atonal music being an 'abnormality', a music capable of a narrow emotional range: that of the frisson and horror only.

While the Musical Accompaniment to a Cinematographic Scene's possible 'program', if we can call it such, might look back to the nightmarish neurasthenia of the earlier pre-war Ewartung or Herzgewasche, Schoenberg's method had changed radically in the intervening years, the system of 'composing with twelve tones' had been developed by him in the early 1920s after a silence from any composing activity. Its musical challenge was to replace the tonal system with an alternative method of organisation while remaining 'pantonal' (Schoenberg thought the term 'atonal' a nonsense). This meant in many ways a more classical basis, a concern with 'pure music' rather than being text driven, and also the development and construction of larger scale pieces. The film music comes hard on the heels of the Variations for Orchestra (1928), Schoenberg's mature twelve-tone orchestral masterpiece, which flexes its structural musical imagination exclusively through the new method. Both scores share something of the same atmosphere, except the film score is smaller in scale and orchestral forces (bespoke, in fact, for cinema orchestras at the time) and seems to reflect a more musical restlessness. In moving from quiet ominous rustlings to fragmented waltz or dance-like propulsions, each are in turn smothered by huge hammer blow crescendos, and here Schoenberg may have had in mind a kind of aural editing. Musical Accompaniment to a Cinematographic Scene occupies an ambiguous space in what has proved to be a tumultuous and transitional phase in music for cinema. Already, by 1929, sound film had arrived two years earlier and sounded the death knell for the kind of cinematic performing traditions that Schoenberg had written for. While he was writing for the "film of the future', the means of production had moved on. Considering the score as film music it is hard not to agree with Berg's regret that Schoenberg had not supervised or created a film, as in 1913, to go with this score. Berg himself, perhaps in response to Schoenberg, was to outline in detail the direction of a silent film to be inserted as the central pivotal point of his opera Lulu (1935). At the posthumous Zurich premiere of the incomplete Lulu in 1937 the film interlude was generally criticized as simply being in the manner of the 'pre-war silent melodramas'. Although since then, the film interlude of this opera (which is filmed with the specific cast for each production) is seen as crucial to the editing and telescoping of time within the musical architecture and plot, as well as being prophetic (as in Schoenberg's predictions) of an opera intertwined with the cinematic ${ }^{10}$.

Musical Accompaniment to a Cinematographic Scene deserves more than being simply an accompaniment 
to stock horror, even if they are drawn from classics of the modernist cinema. Whether the cue titles should be taken literally is a moot point. It has to be said that even in Schoenberg's twelve-tone music which is, generally, more classical than the earlier period, there remains an 'angst', one perhaps rooted in Schoenberg's own history, but remaining none-the-less even in those later works which, according to Adorno, eschew 'animal warmth'. Adorno goes on elsewhere:

We are not dealing with arbitrary behaviour or the preferences of a subjective, unfettered artist, the way people once tried to label him as an 'Expressionist,' for example; nor, equally, are we dealing with the work of a blind craftsman who follows after his material with a calculator, no longer intervening in it spontaneously. ${ }^{11}$

For Adorno, this fissure between subject and object results in an absorption of history, its critical reflection together with the potential formulation of the new, enabling the artwork to act as a critical foil to the real. In this way, catastrophe in Schoenberg, which Adorno suggested, could be felt in every phrase of the composer's music, was neither personal nor objective but literally historically sedimented within the work: an absorbed shock that becomes aesthetically sublated. There is no doubt that the historical moment of his experiences of the Vienna and Berlin of his time are locked within the formation of his output, and yet there is far more than this localised experience there. This is the challenge facing the filmmaker wanting to work with this piece; Adorno's geological metaphor of sedimented layers is apt, but one of the pressing questions in addressing a visual context for the film is: how do we tap into this without any vestige of nostalgia?

\section{Introduction to an Accompaniment to a Cinematographic Scene}

$$
\text { (1973) }
$$

One of the attractions of the Musical Accompaniment to a Cinematographic Scene is, no doubt, a film score by one of the great modern composers - but herein also lies its problem - what do you do with it? Schoenberg's twelve-note method strives for inner musical coherence, but the film score, as Michel Chion has suggested, must remain open and porous if it is to create a meaningful counterpoint with visuals. If Schoenberg's music has its own coherent dramatic shape how does a filmmaker deal with this? Do we think back to his directions to Die Glucklicke Hand, with its parallel 'music for the eye'? Or try and somehow go against it and do something else? Here we can see that the choice of the filmmaker to the conceived soundtrack is a situation of 'counterpoint' (as classic directors from Eisenstein to Hitchcock have demanded of the sound/film relationship) rather than accompaniment as in silent cinema; or rather, the dichotomy between differentiation and complementarity. Do we complement the film scene's visuals or go against them? Or both?

Jean-Marie Straub and Daniel Huillet have produced a collaborative body of work noteworthy for their probing of both aesthetic and political viewpoints within cinema from the late fifties to 2008 when terminated by Huillet's death. As French artists they have commented on European culture within their creative output, examining specific German or Italian cultural concerns through a highly objective and deconstructive lens. Their work responds to the premises of both Brecht and Adorno, without being overly theoretical filmmakers (although, as with Schoenberg himself, that is a common accusation of their work) they have raised issues about the filmmaking process as a politics of looking, listening and participating. Introduction to a Musical Accompaniment 
to a Cinematographic Scene (1973) reflects a long interest in Schoenberg and not just as a composer but also as a broader cultural signifier of modernism with all of its complexities and paradoxes. Their wish to film Schoenberg's Moses and Aron (1930-33 - Schoenberg's spelling) goes back to 1959, finally realized in 1975 in a production featuring the remarkable landscape of the ancient theater of Alba Fucense in the Abruzzi.

As a prelude to this, the short Introduction to a Musical Accompaniment to a Cinematographic Sequence was produced for the German Süd-West-Funk television station as part of a series on composers. In many ways it acts as a commentary both to their realization of the opera, and on the Accompaniment music, and taking on very different form to both. Montage and contrast replaces the massive continuity of the opera realization. Straub/Huillet develop a mode of exposition that attempts to fan out from particulars to cultural generalities. It is, in effect a series of observations on the context of the music: its background, its social environment and its polemical position, without 'representing' or 'illustrating' it. The film begins with a shot of a fountain with the sound of the running water, which relates to the end of a previous film History Lessons. It then cuts to Straub lighting a cigarette on a balcony against a backdrop of Rome, and then talking to the screen about Schoenberg's usual meticulous production directions in contrast to the rather bald cue titles, as Barton Byg points out in his book on Straub/Huillet's German films:

The main argument of Straub's speech is against the proposition that the 'Accompaniment' can be dramatized. Straub quotes the reasons for Schoenberg's detailed stage directions in all his dramatic works, the desire "to leave as little as possible to the new rulers of the theatrical art, the producers." The fact that the Begleitmusik has no such directions, other than the heading "Threatening Danger, Fear, Catastrophe,' proves that the work is not meant to depict directly the events described or foreseen in [Schoenberg's] letters. The work has only an abstract relation to reality. Hence Straub's last assertion, before more neutral biographical narration continues in shot 3, "Otherwise unrepresentable, the cinematographic scene consists only of the so-called accompaniment." 12

In 'Composing for the Films' written with Hanns Eisler in 1946, Adorno comments that the dissonances of Schoenberg's radical period "far surpasses the measure of fear conceivable to the average middle class individual; it is historical fear; a sense of impending doom." It is this trans-subjective historical tide that also embroils the individual that Straub/Huillet then looks to.

Straub's address then picks up on Schoenberg's own situation in the 1920s after showing images of the composer's paintings, mainly the self-portraits. Several incidents developed Schoenberg's insecurity as a European Jew in Austria, perhaps not the first but the most stinging occasion being a vacation at Mattsee near Salzburg in 1922 where Schoenberg was expelled from the resort for being Jewish. In a now infamous 1923 exchange Schoenberg declined Kandinsky's offer to join the faculty at the Bauhaus, as Music Director because he has heard (from exactly where is unclear, but for a while at least he suspected Kandinsky himself) of anti-semitic remarks being made by staff there, and his suspicion. In this impassioned letter to Kandinsky, Schoenberg shows an acute reading of where these anti-semitic tendencies are leading. In many ways these writings are truly prophetic, and full of the threatening danger that may well inform the Accompaniment music. In his 1923 response to Kandinsky's rather lame reply of 'some of my best friends are...', he scathingly writes: 
I have not yet said that for instance when I walk along the street and each person looks at me to see whether I'm a Jew or Christian, I can't very well tell each of them that I'm the one that Kandinsky and some others make an exception of, although of course that man Hitler is not of their opinion [...] but what is anti-semiticism to lead to if not to acts of violence? Is it so difficult to imagine that? You are perhaps satisfied with depriving Jews of their civil rights. Then certainly Einstein, Mahler and I and many others, will have to be gotten rid of. ${ }^{13}$

Gunther Peter Straschek, a film director colleague of Straub/Huillet, takes up the reading of Schoenberg's letter in a studio at the SWDR Studios in Germany. While this is taking place Schoenberg's Musical Accompaniment to a Cinematographic Scene begins and then continues throughout. We then switch to Danielle Huillet stroking a cat (a switch from formal to informal setting - from institutional address to the everyday domestic setting) - here Huillet reads from Brecht. We could say this is in opposition to Schoenberg, the anticommunist (who was livid at all Jews being labelled Bolshevik), who adopted a 'rejection of politics' and who stated in the same letter to Kandinsky:

Trotsky and Lenin spilt rivers of blood (which by the way, no revolution in the history of the world could ever avoid doing) in order to turn a theory - false it goes without saying (but which like those of the philanthropists who brought about previous revolutions, was well meant) - into reality. It is a thing to be cursed and a thing to be punished for he who sets his hands to such things must not make mistakes! ${ }^{14}$

The Brecht reading is taken over by another formal 'lecture' in a studio room, this time by Gerhard Nestler, another director, displaying the recording process itself. Before this, we see still images of the dead bodies of the murdered participants of the Paris commune photographed in their coffins. The reading continues a dialectical opposition to Schoenberg with its foregrounding of Marxist politics in relation to capital, property and the general economic situation leading to Fascism. The next few sequences show the production of napalm bombs being loaded into B52 bombers and documentary footage of a bomber dropping these onto Vietnamese rice fields. The threatening danger traverses the political landscape from the 1870s, to the 1920s politics and become a foil to (then) contemporary catastrophes. The film ends with newspaper cuttings reporting that the architects of the gas chambers and concentration camps have been proven not guilty.

Described so baldly, this might be seen as a proto-didactic piece of political propaganda, but the film remains much more subtle than this. Straub/Huillet's film brilliantly develops a cool, calm counterpoint to the 'heat' of this music. It features blocks of material that dialectically relate. Taking Schoenberg at his word, the music is an accompaniment of sorts - it is spoken over, it is pushed to the background at times, or it becomes a document amongst other documents. But true to Straub's monologue in the film, it is not dramatized. It avoids any illustration of the music, it avoids the magnetic attraction of 'added value' - where sound and image merge, what Michel Chion has called 'Syncresis' of sound and image - which is a mix of synchronicity and synthesis. What Straub and Huillet provide us with is a 'non-syncresis' in the extreme. What it develops is Schoenberg's notion of 'Unreality' on another level - by the utmost realism being transposed through the extremities of the cinematic act; developing an almost complete stillness of the shots: 35 of them in total that relate to the opus number of Schoenberg's piece. As Byg has pointed out, the film mirrors certain formal aspects of the twelve-tone technique (though it has to be said that the results are a world apart) in the sense of heterogeneity and contrast (Adorno's 
reading of Schoenberg's method). And Straub Huillet's Introduction is essentially a montage, dialectically connected with a strong emphasis on the materially of both film and its address. We might be reminded of Schoenberg's idea of not dragging meaning around:

A parallel to Straub/ Huillet and Brecht emerges here. There is no 'resolution' in their work, according to the hierarchical rules of traditional organization of meaning, but the relation of the organization of its materials to these traditional forms implies a resolution outside the work itself [...] The subject of this 'resolution' is outside the work of art but implied by it - [this] is its utopian aspect. ${ }^{15}$

\section{Epilogue}

Straub/ Huillet ask serious questions about Schoenberg's intention of 'unrepresentability', and how images and text can be intertwined to undo any easy notion of how particular representations may be formed. In their realization of a film that denies, in one sense, its presence as a film, any dramatization of the Accompaniment piece would be, for Straub/ Huillet, a travesty. But, the question remains, if such self-cancellation is the last word for this film. Schoenberg himself suggested his faith that the film of the future would be more artistic (than Hollywood at least) - although this remains vague. Straub/ Huillet's carefully framed disruptions, as I mentioned, lead from a kind of realism to an abstraction. Yet Adorno's late writing on film stresses the inescapability of representation within film (which may well bring him in agreement with somebody like Stanley Cavell):

The photographic process of film, primarily representational, places a higher intrinsic significance on the object, as foreign to subjectivity, than aesthetically autonomous techniques; this is the retarding aspect of film in the historical processes of art. Even where film dissolves and modifies its objects as much as it can, the disintegration is never complete. Consequently, it does not permit absolute construction; its elements however abstract, always retains something representational; they are never purely aesthetic values. [...] By virtue of this relationship to the object, the aesthetics of film is thus inherently concerned with society. ${ }^{16}$

In one sense, Straub/ Huillet's Brechtianisms both distance and then reconnect with this cinematic ground of the object and the social.

So would a film that attempts to investigate the cityscapes of Vienna and Berlin betray the essential completeness of Schoenberg's music? Apart from the integrated biographical importance for Schoenberg, another simple answer might be that Modernism, film and the city are, of course, intimately bound up with each other; it would also be an interrogation of these relationships, as well as the whole tradition of what Stephen Barber calls the "film city ${ }^{17}$. Urban experience scars the aesthetic propositions of modernity, which in turn is seen as the direct progeny of the city. This is one reason to re-investigate such images as a critical project. It is the specific experiences of the city that moulds the modernist artwork into being according to writers such as Walter Benjamin, Georg Simmel, and Raymond Williams. In his Aesthetic Theory (1969), Adorno, as suggested earlier, sees the form of the artwork as a kind of sedimentation of content; this is an absorbing of history, which is sublated by aesthetic demands, an important possibly redemptive moment for Adorno. Likewise, the city can also 
be seen as possessing its own kind of sedimentation, bearing its historical scars and harbouring its own ghosts. And in various traditions from Dziga Vertov, Walter Ruttman through to Patrick Kieler and Terence Davies there are ways of reading the city, from archival, mnemonic, historical, fictional, biographical and autobiographical modes of address. Adorno's geological layers are, in fact, materially palpable within the contemporary cityscape. But questions remain regarding this project: How to avoid nostalgia, dramatization (the lessons of Straub/ Huillet) and the monumentalization of the trace? This is bound up with the problems of the approach to the project in itself. Vienna and Berlin would, in Maeve Connolly's term, become 'event-sites' - and possibly explore the idea of Schoenberg through both relevant biographical sites as well as non-sites (in the sense of the city explored in and for itself apart from any connection with the composer), as Connolly suggests:

[...] The prevalence of the material trace, exemplified by the monument, signals a shift from true memory to history. The boundary between memory and history is not entirely fixed, however, and the site of memory is itself characterized by its hybrid form, emerging at the intersection of the material, the functional and the symbolic [...] Artists' cinema certainly encompasses an engagement with the concrete and the spatial, typically responding to or incorporating the traces of architecture or infrastructure. ${ }^{18}$

In this present context, we can also add the temporal and spatial events of sound - from the recorded sound of the city, to Schoenberg's musical Accompaniment; each of these constituting an encounter with the present and the past, of the contemporary 'digital city' corporately hovering simultaneously with its sedimentations of past materiality as well as the ghosts of its own filmic self-image.

\footnotetext{
${ }^{1}$ Lambert, C. (1934), Music Ho! London: Penguin, p.41.

${ }^{2}$ Huntley, J. and Manvell, R. (1957) The Technique of Film Music, New York, London: Focal press, p.19.

${ }^{3}$ Altman, R. (2007) 'Early Film Themes' in Beyond the Soundtrack. Berkeley: University of California, p. 217.

${ }^{4}$ Webern, A. (1912) 'Schonberg's Musik' in Reich, W. ed. (1975) Arnold Schoenberg - The Path to New Music, London: Universal Edition, p.44.

5 Schoenberg, A. (1928), 'Breslau Lecture' in Hahl-Koch, Jelena, and Crawford, John, eds (1984) Arnold Schoenberg, Wassily Kandinsky, Letters, pictures and Documents. Boston, London: Faber and Faber, p. 106.

${ }^{6}$ Schoenberg, A. (c1913) 'On the Projected Film', Ibid.. p.100.

${ }^{7}$ Ibid., p.100.

8 Schoenberg, A. (1927) 'The Future of Opera', Style and Idea, Black, L ed. (1984) Berkeley: University of California, p.336.

${ }^{9}$ Brand, J., Hailey Chr., and Harris, D. (Eds.) (1987), The Berg-Schoenberg Correspondence. London: Macmillan, pp. $400-402$.
} 
10 Schoenberg's relationship to film does not end here. In the 1930 s he was in discussion with MGM for a soundtrack for the 1937 sound film, The Good Earth and actually began sketches. Schoenberg's demand for complete artistic control of the soundtrack apparently was the cause of his departure from the production. In Hollywood Schoenberg also provided a sketch for a 'School for Soundmen' at UCLA, which confirms his continuing interest in scoring for film.

11 Adorno, Th., 'The Dialectical Composer' (1934) in Adorno: Essays on Music, Leppert, Richard, ed (2002), Berkeley: University of California, p. 204-205.

12 Byg, B. (1995), Landscapes of Resistance: The German Films of Straub/Huillet, Berkeley: University of California Press, p. 162.

${ }^{13}$ Hahl-Koch, J., and Crawford, J. (Eds.) (1984) Arnold Schoenberg, Wassily Kandinsky, Letters, pictures and Documents, p.78.

${ }^{14}$ Ibid., p. 81.

${ }^{15}$ Byg, B. (1995), Landscapes of Resistance: The German Films of Straub/Huillet, p. 157.

16 Adorno Th. (1966), 'Transparencies on Film' trans Levin,T.Y. in New German Critique no. 24/25 (Autumn 1981), p. 202.

${ }^{17}$ see Barber, St. (2002), Projected Cities, Cinema and Urban Space, London: Reaktion Books.

${ }^{18}$ Connolly, M. (2009), The Place of Artists' Cinema, University of Chicago: Intellect Books, p.115-116.

David Ryan (PHD) is a visual artist and writer based in London, who is also actively involved in contemporary music. He is currently Reader in Fine Art at Anglia Ruskin University, Cambridge and received his PhD by publication based on his extensive writing on art and music. He took part in a day of music and film at the BFI London entitled Sonic Illuminations, presenting three of his films in 2008. He has also collaborated with Italian composer Nicola Sani including AchaB presented at Huddersfield Contemporary Music Festival (a 3 screen video) in 2008. Ryan has been the recipient numerous awards for his projects including Arts Council of England, BrittenPears; Holst and Hinrichsen Foundations; an American Government Grant, and a Japan Foundation award, as well as other grants. He has also recently worked on the films Knots and Fields: New Music at Darmstadt (2010) with director Andrew Chesher, screened in Darmstadt and New York, and Via di San Teodoro 8 (2010) which has been screened in Rome, Berlin, Stockholm, Seoul and the UK. 